Biogeosciences, 10, 3997-4007, 2013

www.biogeosciences.net/10/3997/2013/

doi:10.5194/bg-10-3997-2013

(C) Author(s) 2013. CC Attribution 3.0 License.

\title{
Photosynthate translocation increases in response to low seawater pH in a coral-dinoflagellate symbiosis
}

\author{
P. Tremblay ${ }^{1,2,3}$, M. Fine ${ }^{4,5}$, J. F. Maguer ${ }^{6}$, R. Grover ${ }^{1,2, *}$, and C. Ferrier-Pagès ${ }^{1,2, *}$ \\ ${ }^{1}$ Centre Scientifique de Monaco, Avenue St-Martin, 98000, Monaco \\ ${ }^{2}$ LEA CSM-CNRS “BIOSENSIB”, 98000, Monaco \\ 3 present address: Département de biologie, chimie et géographie, Université du Québec à Rimouski, \\ 300 allée des Ursulines, Rimouski QC, G5L 3A1, Canada \\ ${ }^{4}$ The Interuniversity Institute for Marine Science in Eilat, P.O. Box 469, Eilat 88103, Israel \\ ${ }^{5}$ The Mina \& Everard Goodman Faculty of Life Sciences, Bar-Ilan University, Ramat Gan 52900, Israel \\ ${ }^{6}$ LEMAR - UMR6539 UBO/CNRS/IRD/IFREMER, Institut Universitaire Européen de la Mer, \\ Place Nicolas Copernic, Plouzané 29280, France \\ *These authors contributed equally to this work.
}

Correspondence to: P. Tremblay (pascale_tremblay@globetrotter.net)

Received: 31 August 2012 - Published in Biogeosciences Discuss.: 3 January 2013

Revised: 24 April 2013 - Accepted: 13 May 2013 - Published: 18 June 2013

\begin{abstract}
This study has examined the effect of low seawater $\mathrm{pH}$ values (induced by an increased $\mathrm{CO}_{2}$ partial pressure) on the rates of photosynthesis, as well as on the carbon budget and carbon translocation in the scleractinian coral species Stylophora pistillata, using a new model based on ${ }^{13} \mathrm{C}$ labelling of the photosynthetic products. Symbiont photosynthesis contributes to a large part of the carbon acquisition in tropical coral species, and it is thus important to know how environmental changes affect this carbon acquisition and allocation. For this purpose, nubbins of $S$. pistillata were maintained for six months at two $\mathrm{pH}_{T} \mathrm{~s}(8.1$ and 7.2, by bubbling seawater with $\mathrm{CO}_{2}$ ). The lowest $\mathrm{pH}$ value was used to tackle how seawater $\mathrm{pH}$ impacts the carbon budget of a scleractinian coral. Rates of photosynthesis and respiration of the symbiotic association and of isolated symbionts were assessed at each $\mathrm{pH}$. The fate of ${ }^{13} \mathrm{C}$ photosynthates was then followed in the symbionts and the coral host for $48 \mathrm{~h}$. Nubbins maintained at $\mathrm{pH}_{T} 7.2$ presented a lower areal symbiont concentration, and lower areal rates of gross photosynthesis and carbon incorporation compared to nubbins maintained at $\mathrm{pH}_{T}$ 8.1. The total carbon acquisition was thus lower under low $\mathrm{pH}$. However, the total percentage of carbon translocated to the host as well as the amount of carbon translocated per symbiont cell were significantly higher under $\mathrm{pH}_{T} 7.2$ than under $\mathrm{pH}_{T} 8.1\left(70 \%\right.$ at $\mathrm{pH}_{T} 7.2$ vs. $60 \%$
\end{abstract}

at $\mathrm{pH}_{T}$ 8.1), such that the total amount of photosynthetic carbon received by the coral host was equivalent under both $\mathrm{pHs}$ (5.5 to $6.1 \mu \mathrm{g} \mathrm{C} \mathrm{cm} \mathrm{h}^{-1}$ ). Although the carbon budget of the host was unchanged, symbionts acquired less carbon for their own needs ( 0.6 compared to $1.8 \mu \mathrm{g} \mathrm{C} \mathrm{cm}{ }^{-2} \mathrm{~h}^{-1}$ ), explaining the overall decrease in symbiont concentration at low $\mathrm{pH}$. In the long term, such decrease in symbiont concentration might severely affect the carbon budget of the symbiotic association.

\section{Introduction}

Changes in seawater chemistry that are induced by an increase in partial-pressure $\mathrm{CO}_{2}\left(p \mathrm{CO}_{2}\right)$ include a decrease in $\mathrm{pH}$, in the carbonate ion $\left(\mathrm{CO}_{3}^{2-}\right)$ concentration and in the saturation states of calcium carbonate minerals (reviewed in Hoegh-Guldberg et al., 2007; Doney et al., 2009). These changes are deleterious for many marine organisms, both for photosynthetic and calcifying species such as tropical scleractinian corals (Kroeker et al., 2010). They may induce a decrease in the $\mathrm{pH}$ at the calcification site of corals (Venn et al., 2013) and a decrease in the calcification rates (reviewed in Erez et al., 2011). Experiments performed at very low pHs $(<7.5)$ to constrain coral physiological performances 
have shown not only a complete decalcification in some coral species but also an increase in tissue biomass and general survival under these extreme conditions (Fine and Tchernov, 2007). Contrary to calcification, the effect of small or large changes in $p \mathrm{CO}_{2} / \mathrm{pH}$ on the physiology of the coral symbionts has been much less studied. However, symbionts, through photosynthesis, are the major actors in the nutrient acquisition of the symbiotic association (Muscatine et al., 1981, 1984; Grover et al., 2002), which in turn is a key process in corals and in animal in general that determines their growth, fecundity and survival.

Coral symbionts, called Symbiodinium, belong to the eukaryotic algal taxon of dinoflagellates. This taxon had form II RuBisCO (ribulose-1,5 bisphosphate carboxylase/oxygenase), which has a low $\mathrm{CO}_{2}$ affinity compared to the other algal taxa (reviewed in Tortell, 2000). Corals have therefore developed carbon-concentrating mechanisms (CCM; Leggat et al., 1999), but it has been suggested that the symbionts in hospite are still limited by the host in dissolved inorganic carbon (DIC) because they are dependent on host bicarbonate $\left(\mathrm{HCO}_{3}^{-}\right)$uptake (Goiran et al., 1996; Marubini and Thake, 1999; Marubini et al., 2008). In theory, an increase in seawater $\mathrm{CO}_{2}$ concentration, leading to a parallel increase in bicarbonate concentration, should increase the rates of symbiont photosynthesis. However, the few studies performed on the subject led to controversial results, differing according to the coral species studied or to the acclimation length to the seawater chemistry changes. Experiments performed on a relatively short-term scale found no effect of acidification ( $\mathrm{pH}$ ranging from 7.5 to 7.9) on areal rates of coral photosynthesis (Scheinder and Erez, 2006; Marubini et al., 2008; Godinot et al., 2011; Houlbrèque et al., 2012) or in the maximum photosynthetic capacity per cell $\left(P_{\mathrm{nmax}}\right.$, Crawley et al., 2010). Longer term experiments at low $\mathrm{pH}$ values (7.4 to 7.8), however, measured a decrease in these rates or in the photosynthetic efficiency of the symbionts (Reynaud et al., 2003; Anthony et al., 2008; Iguchi et al., 2012; Kaniewska et al., 2012), often coupled with bleaching (i.e. the loss of symbionts; Anthony et al., 2008). Only the temperate species Cladocora caespitosa did not significantly change its photosynthesis after being maintained for one year under pH 7.8 (Rodolfo-Metalpa et al., 2010). This different inter-specific response to low $\mathrm{pH}$ might be related both to the extent and/or length of $\mathrm{pH}$ decrease and to the symbiont phylotype, as demonstrated in a recent study (Brading et al., 2011), in which the cell-specific productivity of one phylotype out of four was increased under low $\mathrm{pH}$, while it remained unchanged for the others.

In terms of carbon acquisition for the coral host, not only rates of photosynthesis but also photosynthate translocation rates are important. It is usually assumed that autotrophic carbon acquisition by the host is directly related to the rates of symbiont photosynthesis because symbionts are supposed to translocate more than $90 \%$ of the photosynthates to the host for its own nutrition (Muscatine et al., 1981). However, percentage of translocation may vary according to the host species (Davies, 1984, 1991; Edmunds and Davies, 1986), the symbiont genotype (Loram et al., 2007) or the environment (Muscatine et al., 1984; Tremblay et al., 2012a), and is therefore independent of the production level.

In this study, we measured the fate of the photosynthetically acquired carbon, as well as the amount of carbon translocated from the symbionts to the host, in colonies of the scleractinian coral Stylophora pistillata (Esper, 1797) maintained under two $\mathrm{pH}_{T} \mathrm{~s}$ (8.1 and 7.2) for six months. For this purpose, a new model of carbon translocation (Tremblay et al., 2012b), based on the isotopically labelled ${ }^{13} \mathrm{C}$ bicarbonate, was used. Although the low $\mathrm{pH}$ value chosen in this study is lower than that expected under future climate scenarios, it is useful to examine the physiological response of corals to environmental hypercapnia (Barry et al., 2010). It also helps constrain their boundaries of performance (e.g. Kurihara and Shirayama, 2004) in order to guide subsequent studies on similar taxa. The objectives of our study were thus to determine the effect of decreased $\mathrm{pH}$ on the autotrophic carbon acquisition by the dinoflagellates in symbiosis with $S$. pistillata, and to relate symbiont productivity to carbon acquisition by the coral host. In other words, considering that acidification decreases symbiont productivity in some scleractinian species, do we observe a parallel decrease in carbon acquisition by the host, or does the host maintain its carbon acquisition by increased percentage of carbon translocation?

\section{Materials and methods}

\subsection{Biological material}

Three colonies of the scleractinian coral S. pistillata (Pocilloporidae) were sampled at $10 \mathrm{~m}$ depth in the Gulf of Eilat (Israel). A total of 54 nubbins (18 nubbins per colony) were prepared by cutting the apical branches of the colonies. They were then equally divided (i.e. nine nubbins from each colony) in two tanks $(150 \mathrm{~L})$, which were maintained at two $\mathrm{pH}_{T} \mathrm{~s}: 8.1$ (or $\mathrm{pH}_{N B S}=8.2$ and $p \mathrm{CO}_{2}=387 \mu \mathrm{atm}$, ambient conditions) and 7.2 (or $\mathrm{pH}_{N B S}=7.3$ and $p \mathrm{CO}_{2}=$ $3898 \mu \mathrm{atm}$, Table 1) for six months. For this purpose, seawater was continuously pumped at $30 \mathrm{~m}$ depth into $1000 \mathrm{~L}$ tanks, equipped with a pH electrode (S-200C, Sensorex, CA, USA) connected to a pH controller (Aquastar, IKS Computer System GmbH, Karlsbad, Germany). The controller continuously monitored $\mathrm{pH}$ and adjusted it to the desired value by bubbling $\mathrm{CO}_{2}$ (from a $\mathrm{CO}_{2}$ cylinder). Daily $\mathrm{pH}$ variability was low $( \pm 0.05)$ throughout the experiment, and no major fluctuations were recorded. Well-mixed filtered $(500 \mu \mathrm{m})$ water from each tank continuously flowed into smaller tanks containing the coral nubbins. All $\mathrm{pH}$ data were recorded using monitoring software (Timo, Matuta, Germany) on the NBS scale. The $\mathrm{pH}_{N B S}$ data were shifted onto the total $\mathrm{pH}_{T}$ scale by subtracting 0.1 , which includes a minor correction 
Table 1. Carbonate chemistry parameters of the treatment and the control calculated from $\mathrm{pH}$, total alkalinity (TA), temperature $\left(25^{\circ} \mathrm{C}\right)$ and

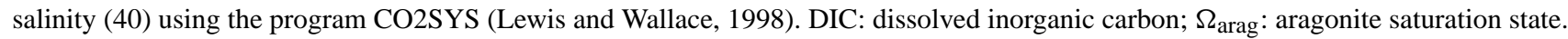

\begin{tabular}{rrrrrrrr}
\hline $\begin{array}{r}\mathrm{pH} \text { total } \\
\text { scale }\left(\mathrm{pH}_{T}\right)\end{array}$ & $\begin{array}{r}\mathrm{TA} \\
\left(\mu \mathrm{eq} \mathrm{kg}{ }^{-1}\right)\end{array}$ & $\begin{array}{r}\mathrm{DIC} \\
\left(\mu \mathrm{mol} \mathrm{kg}{ }^{-1}\right)\end{array}$ & $\begin{array}{r}p \mathrm{CO}_{2} \\
(\mu \mathrm{atm})\end{array}$ & $\begin{array}{r}\mathrm{CO}_{2(\mathrm{aq})} \\
\left.(\mu \mathrm{mol} \mathrm{kg})^{-1}\right)\end{array}$ & $\begin{array}{r}\mathrm{HCO}_{3}^{-} \\
\left(\mu \mathrm{mol} \mathrm{kg}{ }^{-1}\right)\end{array}$ & $\begin{array}{r}\mathrm{CO}_{3}^{2-} \\
\left.(\mu \mathrm{mol} \mathrm{kg})^{-1}\right)\end{array}$ & $\Omega_{\text {arag }}$ \\
\hline 8.1 & 2501 & 2122 & 387 & 10.6 & 1846 & 265 & 4.02 \\
7.2 & 2501 & 2544 & 3898 & 107.1 & 2393 & 44 & 0.67 \\
\hline
\end{tabular}

for $\left[\mathrm{SO}_{4}^{2-}\right]$ and the stability constant of $\mathrm{HSO}_{4}$ at a salinity of 40.7 (Krief et al., 2010). Nubbins were fed once a week with Artemia salina nauplii and mashed fish mix. The tanks were kept under an irradiance of $\sim 140 \mu \mathrm{mol}$ photons $\mathrm{m}^{-2} \mathrm{~s}^{-1}$ (10 h light: $14 \mathrm{~h}$ dark photoperiod) provided by metal halide lamps ( $400 \mathrm{~W} / \mathrm{D}$, Osram $\mathrm{GmbH}$, Germany) in an open-flow system (renewal rate of two times the volume of the basin per day) at $\sim 25^{\circ} \mathrm{C}$. The in situ light level was approximately equal to $280 \mu \mathrm{mol}$ photons $\mathrm{m}^{-2} \mathrm{~s}^{-1}$ at noon. Temperature was regulated using a combination of an array of $300 \mathrm{~W}$ BluClima aquarium heaters (Ferplast Spa, Vicenza, Italy) and a water cooler (custom-made at Interuniversity Institute for Marine Science). From previous studies (Krief et al., 2010), we know that $S$. pistillata grows well under both $\mathrm{pH}_{T} \mathrm{~s}$ for years, and the difference between 7.2 and 8.1 allows us to clearly establish if there is a pH effect on the autotrophic carbon budget of $S$. pistillata. Moreover, the dominant clade of Symbiodinium hosted by colonies of S. pistillata used in this study was determined to the clade level according to Santos et al. (2002) through use of chloroplastic ribosomal deoxyribonucleic acid sequences. In colonies sampled in situ, as well as in nubbins maintained at the two $\mathrm{pHs}$, clade A was dominant and did not change during the experiment.

\subsection{Rates of photosynthesis and respiration}

Rates of respiration $(R)$ and net photosynthesis $\left(P_{\mathrm{n}}\right)$ were measured in each experimental condition using three nubbins (one nubbin per colony). Measurements were performed using temperature-controlled chambers coupled with optodes (ProODO, YSI, Yellow Springs, OH, USA) and filled with $580 \mathrm{~mL}$ of $0.65 \mu \mathrm{m}$-filtered seawater at the right $\mathrm{pH}$. Optodes were calibrated before each measurement using sodium bisulfite $\left(\mathrm{NaHSO}_{3}\right)$ and water-saturated air as 0 and $100 \%$ oxygen saturation values, respectively. Seawater temperature in the chambers was maintained at $25.0 \pm 0.5^{\circ} \mathrm{C}$, and was continuously stirred using magnetic stirrers. For each colony, photosynthesis at $140 \mu \mathrm{mol}$ photons $\mathrm{m}^{-2} \mathrm{~s}^{-1}$ and post-illumination dark respiration were measured over one hour. Rates of gross photosynthesis $\left(P_{\mathrm{g}}\right)$ were calculated by adding $R$ to $P_{\mathrm{n}}$. Samples were then frozen for later determinations of symbionts, chlorophyll $(\mathrm{Chl})$ and protein concentrations. For this purpose, nubbins were thawed and their tissue was detached from the skeleton using an air brush and $0.2 \mu \mathrm{m}$-filtered seawater. The slurry was homogenized using an electric homogenizer (Heidolph DIAX 100 with a generator 6G, Heidolph Instruments $\mathrm{GmbH} \& \mathrm{Co}$. KG, Schwabach, Germany). Subsamples were taken for the determination of the symbiont concentration according to Rodolfo-Metalpa et al. (2006), and protein concentration according to Smith et al. (1985) using the BC Assay Protein Quantitation Kit (Uptima, Interchim) and a Xenius ${ }^{\circledR}$ spectrofluorometer (Safas, Monaco). The remaining sample was used to assess $\mathrm{Chl} a$ and $\mathrm{Chl} c_{2}$ concentrations according to Tremblay et al. (2012c) by use of a spectrophotometer $\mathrm{UVmc}^{2}{ }^{\circledR}$ (Safas, Monaco). Data were subsequently normalized to the skeletal surface area of each nubbin $\left(\mu \mathrm{mol} \mathrm{O}_{2}\right.$ $\mathrm{cm}^{-2} \mathrm{~h}^{-1}$ ) measured using the wax-dipping technique (Veal et al., 2010) or per symbiont cell $\left(\mu \mathrm{mol} \mathrm{O} \mathrm{O}_{2}\right.$ cell $\left.^{-1} \mathrm{~h}^{-1}\right)$.

In addition to the above measurements, respiration rates of freshly isolated symbionts were also determined from three nubbins per condition (one per colony). Symbionts were therefore extracted in $0.65 \mu \mathrm{m}$-filtered seawater at the right $\mathrm{pH}$ using an air brush, homogenized and centrifuged at $3000 \mathrm{~g}$ for $5 \mathrm{~min}$. The pellet, containing the symbionts was resuspended in $0.65 \mu \mathrm{m}$-filtered seawater at the right $\mathrm{pH}$. Respiration rates and symbiont concentration were measured as described above.

The autotrophic carbon acquired $\left(P_{\mathrm{C}}\right)$ and respired $\left(R_{\mathrm{C}}\right)$ was calculated for each treatment, by converting oxygen fluxes to carbon equivalents using the molar weights, as $P_{\mathrm{C}}=$ $P_{\mathrm{g}} \times 12 / P Q$ and $R_{\mathrm{C}}=R \times 12 \times R Q$ (Anthony and Fabricius, 2000 ), where $P Q$ and $R Q$ are photosynthetic and respiratory quotients equal to $1.1 \mathrm{~mol} \mathrm{O}_{2}: \mathrm{mol} \mathrm{C}$ and $0.8 \mathrm{~mol} \mathrm{C}: \mathrm{mol} \mathrm{O}_{2}$, respectively, for S. pistillata of the Red Sea (Muscatine et al., 1981; Gattuso and Jaubert, 1990).

\section{$2.3 \quad \mathrm{H}^{13} \mathrm{CO}_{3}$ labelling experiments}

The experiments were performed according to Tremblay et al. (2012b). Briefly, corals were placed in $\mathrm{H}^{13} \mathrm{CO}_{3}^{-}$ $\left(\mathrm{NaH}^{13} \mathrm{CO}_{3} 98\right.$ atom $\%{ }^{13} \mathrm{C}$, \#372382, Sigma-Aldrich, StLouis, MO, USA) enriched seawater and then transferred into non-enriched seawater for various chase periods. At the end, samples were frozen for later ${ }^{13} \mathrm{C}$ enrichment measurements in the symbionts and coral tissue.

For each condition, 15 beakers were therefore filled with $200 \mathrm{~mL}$ of seawater at the right $\mathrm{pH}$, enriched with a concentration of $0.6 \mathrm{mM} \mathrm{NaH}{ }^{13} \mathrm{CO}_{3}$ (or $23 \%{ }^{13} \mathrm{C}$ enrichment of 
Table 2. List of symbols, definition and units.

\begin{tabular}{|c|c|}
\hline Symbol & Definition \\
\hline $\mathrm{C}$ & Carbon \\
\hline$C_{\text {inc }}$ & ${ }^{13} \mathrm{C}$ enrichment of the incubation medium (\%) \\
\hline$C_{\mathrm{L}}$ & Amount of $\mathrm{C}$ lost $\left(\mu \mathrm{g} \mathrm{C} \mathrm{cm}{ }^{-2} \mathrm{~h}^{-1}\right.$ or $\left.\%\right)$ \\
\hline$C_{\text {meas }}$ & ${ }^{13} \mathrm{C}$ measured in the sample $(\%)$ \\
\hline$C_{\text {nat }}$ & Natural abundance in ${ }^{13} \mathrm{C}$ in control nubbins $(\%)$ \\
\hline$C_{\mathrm{R}}$ & Percentage of fixed $\mathrm{C}$ remaining in symbionts and host tissue $(\%)$ \\
\hline$M_{\mathrm{C}}$ & Mass of $\mathrm{C}$ per milligram of tissue or symbionts $\left(\mu \mathrm{g} \mathrm{mg}^{-1}\right)$ \\
\hline$M_{\text {sample }}$ & Mass of the freeze-dried sample (mg) \\
\hline$P_{\mathrm{C}}$ & Gross $\mathrm{C}$ fixed photosynthetically by symbionts $\left(\mu \mathrm{g} \mathrm{C} \mathrm{cm}^{-2} \mathrm{~h}^{-1}\right)$ \\
\hline$P_{\mathrm{g}}$ & Oxygen produced by gross photosynthesis $\left(\mu \mathrm{mol} \mathrm{O} \mathrm{Cm}^{-2} \mathrm{~h}^{-1}\right)$ \\
\hline$P_{\mathrm{n}}$ & Oxygen produced by net photosynthesis $\left(\mu \mathrm{mol} \mathrm{O}_{2} \mathrm{~cm}^{-2} \mathrm{~h}^{-1}\right)$ \\
\hline$P Q$ & Photosynthetic quotient (equal to $1.1 \mathrm{~mol} \mathrm{O}_{2}: \mathrm{mol} \mathrm{C}$ ) \\
\hline$R$ & Oxygen consumed by respiration of holobiont $\left(\mu \mathrm{mol} \mathrm{O}_{2} \mathrm{~cm}^{-2} \mathrm{~h}^{-1}\right)$ \\
\hline$R_{\mathrm{C}}$ & $\mathrm{C}$ respired by holobiont $\left(\mu \mathrm{g} \mathrm{C} \mathrm{cm}^{-2} \mathrm{~h}^{-1}\right)$ \\
\hline$R_{\mathrm{H}}$ & $\mathrm{C}$ respired by coral host $\left(\mu \mathrm{g} \mathrm{C} \mathrm{cm}^{-2} \mathrm{~h}^{-1}\right)$ \\
\hline$R Q$ & Respiratory quotient (equal to $0.8 \mathrm{~mol} \mathrm{C:} \mathrm{mol} \mathrm{O}_{2}$ ) \\
\hline$R_{\mathrm{S}}$ & $\mathrm{C}$ respired by symbionts $\left(\mu \mathrm{g} \mathrm{C} \mathrm{cm}^{-2} \mathrm{~h}^{-1}\right)$ \\
\hline$S$ & Nubbin surface area $\left(\mathrm{cm}^{2}\right)$ \\
\hline$T_{\mathrm{S}}$ & Amount of $\mathrm{C}$ translocated; calculated from the symbiont rates $\left(\mu \mathrm{g} \mathrm{C} \mathrm{cm}{ }^{-2} \mathrm{~h}^{-1}\right.$ or $\left.\%\right)$ \\
\hline$t_{\text {chase }}$ & Incubation time of the nubbins in the non-enriched incubation medium in the light $(\mathrm{h})$ \\
\hline$t_{\text {pulse }}$ & Incubation time of the nubbins in the enriched incubation medium (h) \\
\hline$\rho_{\mathrm{DOC}}$ & $\mathrm{C}$ incorporation rate in released DOC (not measured) \\
\hline$\rho_{\mathrm{H}}$ & $\mathrm{C}$ incorporation rate in coral tissue $\left(\mu \mathrm{g} \mathrm{C} \mathrm{cm}{ }^{-2} \mathrm{~h}^{-1}\right)$ \\
\hline$\rho_{\mathrm{POC}}$ & $\mathrm{C}$ incorporation rate in released POC (not measured) \\
\hline$\rho_{\mathrm{S}}$ & $\mathrm{C}$ incorporation rate in symbiont $\left(\mu \mathrm{g} \mathrm{C} \mathrm{cm}^{-2} \mathrm{~h}^{-1}\right)$ \\
\hline
\end{tabular}

the incubation medium) and maintained at the same irradiance and temperature as described previously. Fifteen nubbins (five per colony) were individually incubated over $5 \mathrm{~h}$ in the ${ }^{13} \mathrm{C}$-enriched seawater and thereafter transferred into 15 other beakers containing non-enriched seawater at the right $\mathrm{pH}$ (chase). Three nubbins (one per colony) were removed after $0,2,4,24$ and $48 \mathrm{~h}$ and immediately frozen at $-20^{\circ} \mathrm{C}$. Six control nubbins per condition (two per colony; incubated from the beginning in $200 \mathrm{~mL}$ non-enriched seawater) were run in parallel and two were sampled after 0, 24 and $48 \mathrm{~h}$ and immediately frozen at $-20^{\circ} \mathrm{C}$. The $\mathrm{pH}_{N B S}$ was controlled after addition of the ${ }^{13} \mathrm{C}$ bicarbonate and during the whole experiment to ensure that it remained at the desired level, especially for the low $\mathrm{pH}$ condition.

All nubbins were treated according to Tremblay et al. (2012b). Briefly, tissue was detached from the skeleton using an air brush in $0.2 \mu \mathrm{m}$-filtered seawater. The slurry was homogenized using an electric homogenizer (Heidolph DIAX 100 with a generator 6G), and the animal and symbionts fractions separated by centrifugation. Samples were frozen and freeze-dried until analysis. The $\%{ }^{13} \mathrm{C}$ and the carbon content of the animal tissue and symbionts were determined with a mass spectrometer (Delta Plus, Thermofisher Scientific, Bremen, Germany) coupled with a C/N analyser (Flash EA, Thermofisher Scientific).

\subsection{Autotrophic carbon budget calculations}

The equations used to calculate autotrophic carbon budget are fully described in Tremblay et al. (2012b). However, in the present study, $\rho_{\mathrm{POC}}$ was not measured and the equations were adjusted accordingly and listed below. The carbon incorporation rate $(\rho)$ in the symbionts $\left(\rho_{\mathrm{S}}\right)$ and animal tissue $\left(\rho_{\mathrm{H}}\right)$, expressed in $\mu \mathrm{g} \mathrm{C} \mathrm{cm}^{-2} \mathrm{~h}^{-1}$ was calculated as follows:

$\rho=\frac{\left(C_{\text {meas }}-C_{\text {nat }}\right) \times M_{\text {sample }} \times M_{\mathrm{C}}}{\left(C_{\text {inc }}-C_{\text {meas }}\right) \times\left(t_{\text {pulse }}+t_{\text {chase }}\right) \times S}$,

where $C_{\text {meas }}$ and $C_{\text {nat }}$ are the percentages of ${ }^{13} \mathrm{C}$ measured in enriched and control samples, respectively, $C_{\text {inc }}$ is the percent ${ }^{13} \mathrm{C}$ enrichment of the seawater (which varies during the chase; see Tremblay et al., 2012b), $M_{\text {sample is the mass of }}$ the sample $(\mathrm{mg}), M_{\mathrm{C}}$ is the carbon content per symbiont or host tissue biomass $\left(\mu \mathrm{g} \mathrm{mg}^{-1}\right), S$ is the surface area $\left(\mathrm{cm}^{2}\right)$, $t_{\text {pulse }}$ and $t_{\text {chase }}$ are the incubation time (h) in the enriched incubation medium and non-enriched medium in the light, respectively. See Table 2 for a list of symbols and their definitions.

The percentage of fixed carbon remaining $\left(C_{\mathrm{R}}\right)$ in symbionts and host tissue is calculated by dividing $\rho_{\mathrm{S}}$ or $\rho_{\mathrm{H}}$ by the gross photosynthesis expressed in carbon $\left(P_{\mathrm{C}}\right)$, and then 
multiplying by 100 :

$C_{\mathrm{R}}=\left(\rho_{\mathrm{S}}\right.$ or $\left.\rho_{\mathrm{H}} / P_{\mathrm{C}}\right) \times 100$.

The carbon acquired through photosynthesis $\left(P_{\mathrm{C}}\right)$ may have different fates: it is either respired by the coral assemblage $\left(R_{\mathrm{C}}\right)$, incorporated into the symbiont $\left(\rho_{\mathrm{S}}\right)$ and host $\left(\rho_{\mathrm{H}}\right)$ biomass or lost in the surrounding water as POC $\left(\rho_{\mathrm{POC}}\right)$ and DOC $\left(\rho_{\text {DOC }}\right)$. Therefore, the carbon budget equation is

$P_{\mathrm{C}}=R_{\mathrm{C}}+\rho_{\mathrm{S}}+\rho_{\mathrm{H}}+\rho_{\mathrm{POC}}+\rho_{\mathrm{DOC}}$.

$R_{\mathrm{C}}$ includes two components, i.e. symbiont $\left(R_{\mathrm{S}}\right)$ and host $\left(R_{\mathrm{H}}\right)$ respiration; $R_{\mathrm{S}}+R_{\mathrm{H}}=R_{\mathrm{C}}$.

The above equation does not consider the carbon incorporated in the skeleton because it has been shown that 25 to $30 \%$ comes directly from the external medium as dissolved inorganic carbon, and 70 to $75 \%$ from internal respiration $R_{\mathrm{C}}$ (Erez, 1978; Furla et al., 2000); the first component is external to the equation, and the second component is part of $R_{\mathrm{C}}$. It follows from Eq. (3) that the amount of carbon lost as combined $R_{\mathrm{C}}, \rho_{\mathrm{DOC}}$ and $\rho_{\mathrm{POC}}\left(C_{\mathrm{L}}\right)$ is

$C_{\mathrm{L}}=R_{\mathrm{C}}+\rho_{\mathrm{DOC}}+\rho_{\mathrm{POC}}=P_{\mathrm{C}}-\rho_{\mathrm{S}}-\rho_{\mathrm{H}}$.

The amount of carbon translocated by symbionts to the host $\left(T_{\mathrm{S}}\right)$ corresponds to the total amount of carbon gained by photosynthesis $\left(P_{\mathrm{C}}\right)$ minus the sum of the carbon retained in symbionts $\left(\rho_{\mathrm{S}}\right)$ and respired by them $\left(R_{\mathrm{S}}\right)$ :

$T_{\mathrm{S}}=P_{\mathrm{C}}-\rho_{\mathrm{S}}-R_{\mathrm{S}}$.

The percentage of carbon lost $\left(C_{\mathrm{L}}\right)$ and translocated $\left(T_{\mathrm{S}}\right)$ was obtained by dividing $C_{\mathrm{L}}$ or $T_{\mathrm{S}}$ by $P_{\mathrm{C}}$ and multiplying by 100.

In the present study, $\rho_{\mathrm{DOC}}$ and $\rho_{\mathrm{POC}}$ were not measured but estimated from the carbon lost equation (Eq. 4):

$\rho_{\mathrm{DOC}}+\rho_{\mathrm{POC}}=C_{\mathrm{L}}-R_{\mathrm{C}}=\left(P_{\mathrm{C}}-\rho_{\mathrm{S}}-\rho_{\mathrm{H}}\right)-R_{\mathrm{C}}$.

\subsection{Statistical analysis}

All parameters were expressed as average value \pm standard error of the mean (s.e.m.). Data were checked for normality using a Kolmogorov-Smirnov test with Lilliefors correction and for variance homoscedasticity using a Levene test. When the conditions were not fulfilled, data were transformed (natural logarithm for protein content). Significant differences in physiological parameters were tested using a $t$ test. The effect of $\mathrm{pH}$ on the incorporation rates $(\rho)$, the percentage of fixed carbon remaining $\left(C_{\mathrm{R}}\right)$, the carbon lost $\left(C_{\mathrm{L}}\right)$ and carbon translocation $\left(T_{\mathrm{S}}\right)$ was tested using a repeated measures analysis of variance (ANOVA). Colonies were considered as "subjects", while $\mathrm{pH}$ was the between subject factor. The second factor was time over the course of the chase interval, and had five levels (0, 2, 4, 24 and $48 \mathrm{~h})$. The repeated measures ANOVA was followed by a posteriori test (Tukey test) if significant. Differences in the amount of carbon lost $\left(C_{\mathrm{L}}\right)$ and
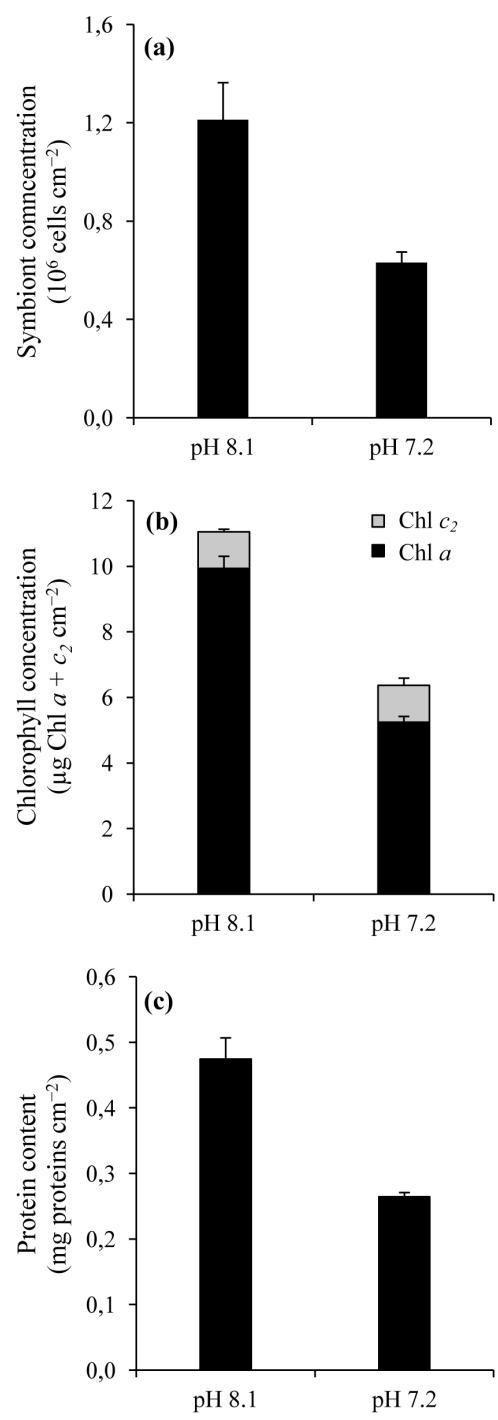

Fig. 1. (a) Symbiont, (b) chlorophyll and (c) protein concentrations for Stylophora pistillata at $\mathrm{pH}_{T} 8.1$ and 7.2. Data are means \pm standard error of means of $n=4$ measurements.

total respiration rates of the nubbins $\left(R_{\mathrm{C}}\right)$ were tested using a $t$ test. Differences between factors were considered significant for a $p$ value $<0.05$. Statistics were performed using Systat 13 (Systat Software, Chicago, IL, USA).

\section{Results}

\subsection{Effect of seawater $\mathrm{pH}$ on the main physiological parameters}

Carbonate chemistry parameters in the different conditions are presented in Table 1. Seawater acidification induced significant differences in several physiological parameters of S. pistillata (Figs. 1 and 2). Areal symbiont concentration was $48 \%$ lower at $\mathrm{pH}_{T} 7.2$, compared to $\mathrm{pH}_{T} 8.1$ (Fig. 1a, 

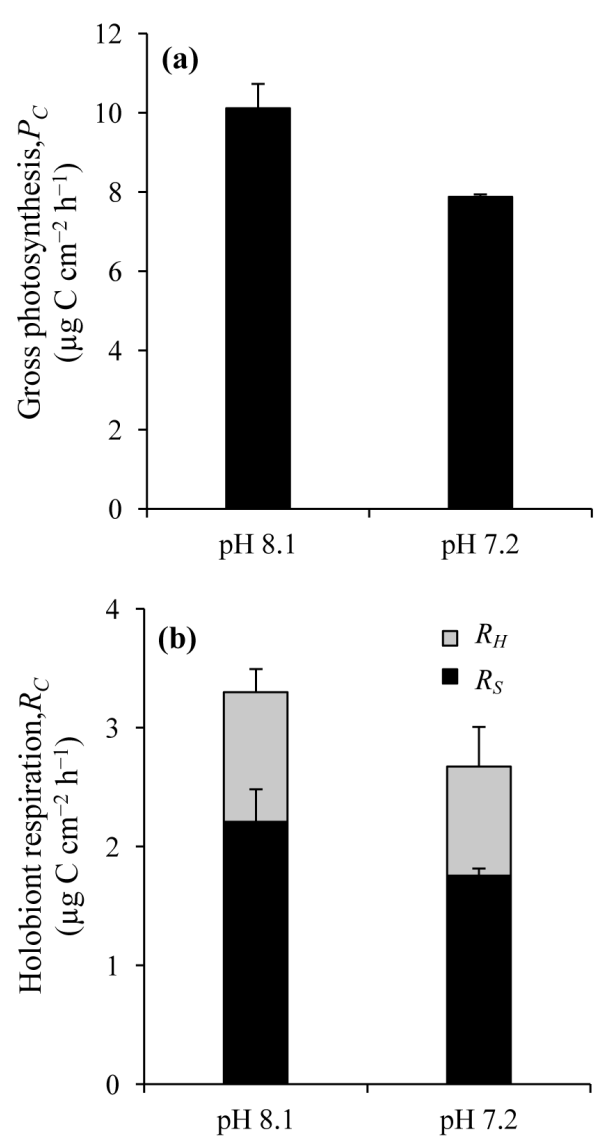

Fig. 2. (a) Gross photosynthesis $\left(P_{\mathrm{C}}\right)$ and (b) holobiont respiration $\left(R_{\mathrm{C}}=R_{\mathrm{S}}+R_{\mathrm{H}}\right)$ for Stylophora pistillata at $\mathrm{pH}_{T} 8.1$ and 7.2. Data are means \pm standard error of means of $n=3$ measurements.

$t$ test $p=0.0045 ; t=4.42 ; \mathrm{d} f=6$ ), combined with a $42 \%$ decrease in areal $\mathrm{Chl} a$ concentration at $\mathrm{pH}_{T} 7.2$, compared to $\mathrm{pH}_{T} 8.1$ (Fig. $1 \mathrm{~b}, t$ test $p<0.0001 ; t=12.85 ; \mathrm{d} f=6$ ). On the contrary, there was no difference in areal $\mathrm{Chl} c_{2}$ concentration between the two treatments (Fig. 1b, $t$ test $p=0.8097 ; t=0.25 ; \mathrm{d} f=6$ ). Protein content was significantly lower at $\mathrm{pH}_{T} 7.2$, compared to $\mathrm{pH}_{T} 8.1$ (Fig. $1 \mathrm{c}, t$ test $p=0.0010 ; t=6.83 ; \mathrm{d} f=5$ ).

As a result of low symbiont and chlorophyll concentrations in corals maintained under $\mathrm{pH}_{T} 7.2$, areal rates of gross photosynthesis were $22 \%$ lower at this $\mathrm{pH}$ compared to those measured at $\mathrm{pH}_{T} 8.1$ (Fig. 2a, $t$ test $p=0.0153 ; t=4.06$; $\mathrm{d} f=4$ ), whereas the respiration rates were similar (Fig. 2b, $t$ test $p=0.1286 ; t=1.91 ; \mathrm{d} f=4)$, corresponding to ca. $72 \mu \mathrm{g} \mathrm{C} \mathrm{cm} \mathrm{cm}^{-2} \mathrm{~d}^{-1}$ in both conditions. Gross photosynthesis therefore supplied $22 \%$ less carbon to nubbins maintained under $\mathrm{pH}_{T} 7.2\left(79 \pm 1 \mu \mathrm{g} \mathrm{C} \mathrm{cm}^{-2} \mathrm{~d}^{-1}\right)$ compared to those maintained under $\mathrm{pH}_{T} \quad 8.1\left(101 \pm 6 \mu \mathrm{g} \mathrm{Cm}^{-2} \mathrm{~d}^{-1}\right)$. When photosynthetic rates were normalized per symbiont cell (cell-specific productivity), they were slightly but significantly higher $(t$ test $p=0.0347 ; t=3.15 ; \mathrm{d} f=4)$ un-
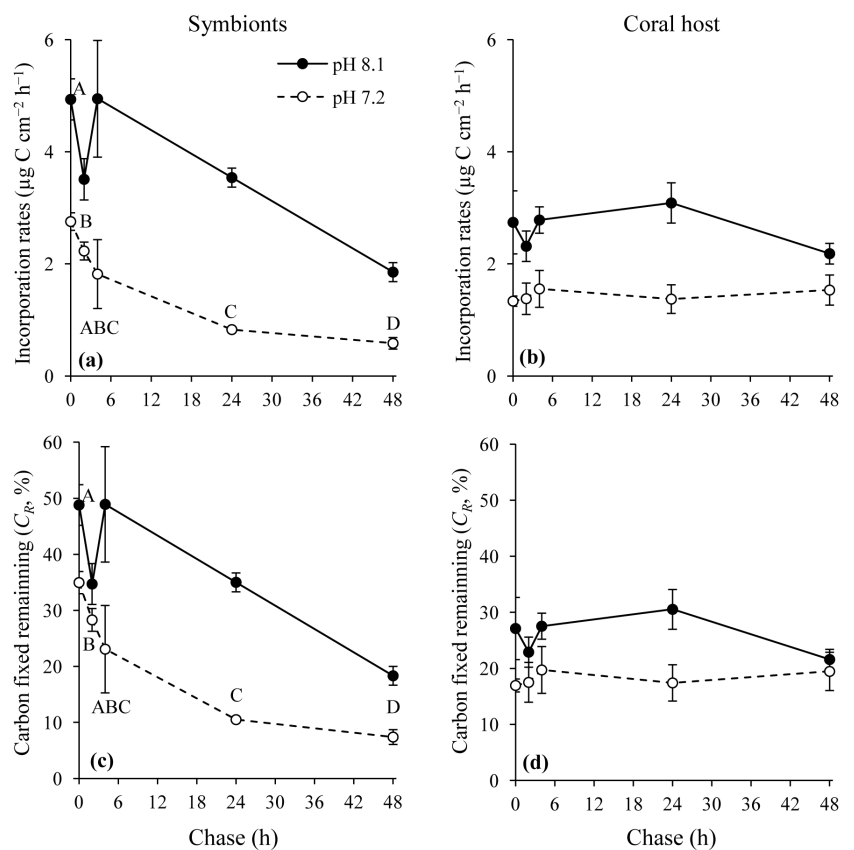

Fig. 3. Carbon incorporation rates $(\rho)$ in (a) symbionts and (b) coral host. Percentage of fixed carbon that remains $\left(C_{\mathrm{R}}\right)$ in the (c) symbionts and (d) host for Stylophora pistillata at $\mathrm{pH}_{T}$ 8.1 and 7.2. Data are means \pm standard error of means of $n=3$ measurements. Chase intervals with different letters (A to D) are significantly different.

der $\mathrm{pH}_{T} 7.2\left(11.8 \pm 0.5 \times 10^{-6} \mu \mathrm{g} \mathrm{C}\right.$ cell $\left.^{-1} \mathrm{~h}^{-1}\right)$ than under $\mathrm{pH}_{T} 8.1\left(9.4 \pm 0.6 \times 10^{-6} \mu \mathrm{g} \mathrm{C}\right.$ cell ${ }^{-1} \mathrm{~h}^{-1}$; not shown in a figure).

\subsection{Carbon translocation between the symbionts and their host}

The natural percentage of ${ }^{13} \mathrm{C}$ (measured in non-enriched control samples) was lower at $\mathrm{pH}_{T} 7.2(1.1224 \pm 0.0002$ and $1.1222 \pm 0.0001$ atom $\%^{13} \mathrm{C}$ for symbiont and coral tissue, respectively) than at $\mathrm{pH}_{T} 8.1(1.1294 \pm 0.0014$ and $1.1306 \pm 0.0004$ atom $\%{ }^{13} \mathrm{C}$, respectively). After incubation in ${ }^{13} \mathrm{C}$ bicarbonate, nubbins from both conditions were however enriched in ${ }^{13} \mathrm{C}$ compared to control samples (atom $\%{ }^{13} \mathrm{C}$ ranged between 1.6296 and $3.0147 \%$ in symbionts, and between 1.3015 and $1.3877 \%$ in the host tissue).

Carbon incorporation rates at the beginning of chase interval $(0 \mathrm{~h})$ in the symbionts and host tissue were twice lower under $\mathrm{pH}_{T} 7.2$ (2.8 and $1.3 \mu \mathrm{g} \mathrm{C} \mathrm{cm} \mathrm{cm}^{-2} \mathrm{~h}^{-1}$, respectively) than under $\mathrm{pH}_{T} 8.1$ (4.9 and $2.7 \mu \mathrm{g} \mathrm{Cm}^{-2} \mathrm{~h}^{-1}$, respectively; Fig. 3a, b and Table 3). The amount of carbon retained in symbionts decreased during the chase to reach 0.6 and $1.8 \mu \mathrm{g}$ $\mathrm{C} \mathrm{cm}^{-2} \mathrm{~h}^{-1}$ in nubbins maintained at $\mathrm{pH}_{T} 7.2$ and 8.1, respectively (Fig. 3a and Table 3). As a consequence, only 8 to $18 \%$ remained in this fraction after $48 \mathrm{~h}$ (Fig. $3 \mathrm{c}$ and Table 3). In contrast, carbon retained in the coral tissue remained more or less constant during the whole chase (Fig. 3b 
Table 3. Results of the repeated measures analysis of variance (ANOVA) testing the effect of $\mathrm{pH}$ and incubation time on the carbon incorporation rates $(\rho)$ and percentage of fixed carbon $\left(C_{\mathrm{R}}\right)$ in the symbionts and coral host. Significant $p$ values are in bold.

\begin{tabular}{|c|c|c|c|c|c|}
\hline \multirow[t]{2}{*}{ Factor } & \multirow{2}{*}{$\begin{array}{r}\text { Degrees of } \\
\text { freedom }\end{array}$} & \multicolumn{2}{|c|}{ Symbionts } & \multicolumn{2}{|c|}{ Coral host } \\
\hline & & $p$ & $F$ value & $p$ & $F$ value \\
\hline \multicolumn{6}{|c|}{ Incorporation rate $(\rho)$} \\
\hline \multicolumn{6}{|c|}{ Between subjects } \\
\hline $\mathrm{pH}$ & 1 & 0.0005 & 103.30 & 0.0060 & 28.36 \\
\hline Error & 4 & - & - & - & - \\
\hline \multicolumn{6}{|c|}{ Within subjects } \\
\hline Time & 4 & 0.0002 & 10.44 & 0.5992 & 0.71 \\
\hline Time $\times \mathrm{pH}$ & 4 & 0.1968 & 1.71 & 0.4432 & 0.99 \\
\hline Error & 16 & - & - & - & - \\
\hline \multicolumn{6}{|c|}{ Fixed carbon remaining $\left(C_{\mathrm{R}}\right)$} \\
\hline \multicolumn{6}{|c|}{ Between subjects } \\
\hline $\mathrm{pH}$ & 1 & 0.0026 & 44.59 & 0.0454 & 8.25 \\
\hline Error & 4 & - & - & - & - \\
\hline \multicolumn{6}{|c|}{ Within subjects } \\
\hline Time & 4 & 0.0001 & 11.66 & 0.6536 & 0.62 \\
\hline Time $\times \mathrm{pH}$ & 4 & 0.2141 & 1.64 & 0.4651 & 0.94 \\
\hline Error & 16 & - & - & - & - \\
\hline
\end{tabular}

and Table 3 ) and corresponded to $19-22 \%$ of the initial fixed carbon (Fig. 3d and Table 3).

The major part of the fixed carbon was lost as respiration and excretion of DOC and/or POC. Total losses accounted for 3.8 and $2.4 \mu \mathrm{g} \mathrm{cm}^{-2} \mathrm{~h}^{-1}$ at the beginning of the chase for corals under $\mathrm{pH}_{T} 7.2$ and 8.1, respectively, and reached 6.1 and $5.8 \mu \mathrm{g} \mathrm{cm}^{-2} \mathrm{~h}^{-1}$ after $48 \mathrm{~h}$ (Fig. 4a and Table 4), corresponding to 60 to $73 \%$ of the fixed carbon (Fig. $4 \mathrm{~b}$ and Table 4). The amount of carbon lost after $48 \mathrm{~h}$ (Fig. 4a), at both pHs, was significantly higher than the respiration rates measured using the respirometry technique (Fig. 2b, $t$ test $p=0.0025 ; t=6.76 ; \mathrm{d} f=4$ for $\mathrm{pH}_{T} 7.2$ and $t$ test $p=0.0020 ; t=7.22 ; \mathrm{d} f=4$ for $\mathrm{pH}_{T} 8.1$ ). These results suggest that the release of autotrophic carbon as DOC and POC must have accounted for a significant fraction of the carbon lost. Indeed, the difference between the $C_{\mathrm{L}}$ and $R_{\mathrm{C}}$ values after $48 \mathrm{~h}$ was equal to 3.1 and $2.8 \mu \mathrm{g} \mathrm{Cm}^{-2} \mathrm{~h}^{-1}$ or 39 and $27 \%$ of the fixed carbon for nubbins under $\mathrm{pH}_{T} 7.2$ and 8.1, respectively.

Carbon translocation rates are represented in Fig. $4 \mathrm{c}$ and d. The total amount of carbon translocated per skeletal surface area was similar under the two pHs (Fig. 4c and Table 4), despite higher areal rates of photosynthesis under $\mathrm{pH}_{T} 8.1$ (Fig. 2a), and increased with time (Fig. 4c and Table 4). Therefore, the percentage of the total fixed carbon translocated was significantly higher at $\mathrm{pH}_{T} 7.2$ than at $\mathrm{pH}_{T} 8.1$ (Fig. $4 \mathrm{~d}$ and Table 4). Indeed, $70 \%$ of the fixed carbon was translocated to the host after $48 \mathrm{~h}$ at $\mathrm{pH}_{T} 7.2$ compared to $60 \%$ at $\mathrm{pH}_{T} 8.1$ (Fig. $4 \mathrm{~d}$ ). Moreover, due to lower areal symbiont concentration at $\mathrm{pH}_{T} 7.2$ compared to $\mathrm{pH}_{T}$ 8.1, the amount of carbon translocated per symbiont cell was $40 \%$ higher after $48 \mathrm{~h}$ in symbionts of nubbins maintained at $\mathrm{pH}_{T} 7.2\left(8.8 \pm 0.2 \times 10^{-6} \mu \mathrm{g} \mathrm{C}\right.$ cell $\left.^{-1} \mathrm{~h}^{-1}\right)$ than in symbionts of corals under $\mathrm{pH}_{T} 8.1\left(5.0 \pm 0.1 \times 10^{-6} \mu \mathrm{g} \mathrm{C}\right.$ cell $^{-1} \mathrm{~h}^{-1}$; not shown in a figure).

\section{Discussion}

Exposure of S. pistillata to $\mathrm{pH}_{T}$ of 7.2 led to a reduction in areal symbiont concentration and subsequently in the areal rates of gross photosynthesis compared to control corals maintained at $\mathrm{pH}_{T}$ 8.1. However, this decreased capacity in autotrophic carbon acquisition under low $\mathrm{pH}$ was counterbalanced by a higher percentage of carbon translocation, leading to an equivalent amount of autotrophic carbon acquired by the host in both $\mathrm{pH}$ conditions.

As previously and recently observed for one clade of Symbiodinium, clade A2 (Brading et al., 2011), cell-specific productivity in the present study was increased under low $\mathrm{pH}$ - i.e. under high seawater $\mathrm{CO}_{2}$ and bicarbonate concentrations. The higher cell-specific productivity observed under $\mathrm{pH}_{T} 7.2$ compared to $\mathrm{pH}_{T} 8.1$ could be due to the direct effect of increased $\mathrm{CO}_{2}$ /bicarbonate in seawater or to the indirect "bleaching effect", which decreased areal symbiont concentration in the host tissue and therefore increased the availability of light and DIC for each symbiont cell. This suggests that in hospite symbionts of $S$. pistillata are DIC limited. Such limitation was already observed in two previous studies (Goiran et al., 1996; Marubini et al., 2008). Marubini et al. (2008) indeed measured an increase in areal rates of gross photosynthesis of $S$. pistillata 
Table 4. Results of the repeated measures analysis of variance (ANOVA) testing the effect of $\mathrm{pH}$ and incubation time on the amount and percentage of carbon lost $\left(C_{\mathrm{L}}\right)$ and translocated $\left(T_{\mathrm{S}}\right)$. Significant $p$ values are in bold.

\begin{tabular}{|c|c|c|c|c|c|}
\hline \multirow[t]{2}{*}{ Factor } & \multirow{2}{*}{$\begin{array}{r}\text { Degrees of } \\
\text { freedom }\end{array}$} & \multicolumn{2}{|c|}{ Amount $\left(\mu \mathrm{g} \mathrm{C} \mathrm{cm}{ }^{-2} \mathrm{~h}^{-1}\right)$} & \multicolumn{2}{|c|}{ Percentage $(\%)$} \\
\hline & & $p$ & $F$ value & $p$ & $F$ value \\
\hline \multicolumn{6}{|c|}{ Carbon lost $\left(C_{\mathrm{L}}\right)$} \\
\hline \multicolumn{6}{|c|}{ Between subjects } \\
\hline $\mathrm{pH}$ & 1 & 0.0461 & 8.15 & 0.0067 & 26.66 \\
\hline Error & 4 & - & - & - & - \\
\hline \multicolumn{6}{|c|}{ Within subjects } \\
\hline Time & 4 & 0.0071 & 5.20 & 0.0052 & 5.60 \\
\hline Time $\times \mathrm{pH}$ & 4 & 0.2513 & 1.49 & 0.2972 & 1.34 \\
\hline Error & 16 & - & - & - & - \\
\hline \multicolumn{6}{|c|}{ Carbon translocation $\left(T_{\mathrm{S}}\right)$} \\
\hline \multicolumn{6}{|c|}{ Between subjects } \\
\hline $\mathrm{pH}$ & 1 & 0.1828 & 2.59 & 0.0029 & 42.03 \\
\hline Error & 4 & - & - & - & - \\
\hline \multicolumn{6}{|c|}{ Within subjects } \\
\hline Time & 4 & 0.0002 & 10.44 & 0.0001 & 11.64 \\
\hline Time $\times \mathrm{pH}$ & 4 & 0.1968 & 1.71 & 0.2162 & 1.63 \\
\hline Error & 16 & - & - & - & - \\
\hline
\end{tabular}
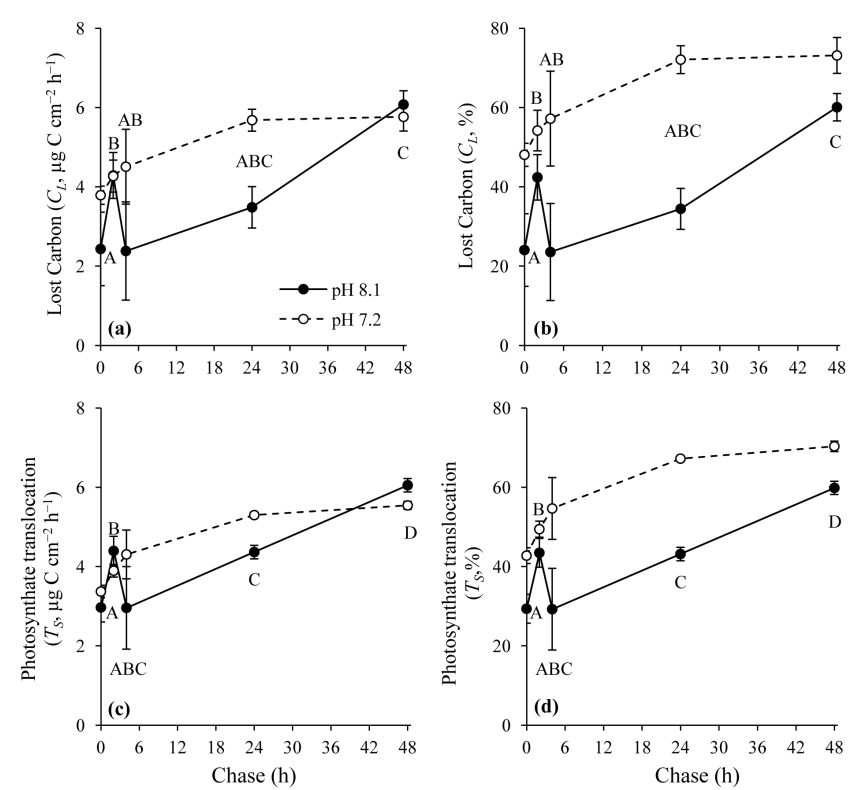

Fig. 4. (a) Amount and (b) percentage of carbon lost by symbiosis $\left(C_{\mathrm{L}}\right)$; (c) amount and (d) percentage of photosynthesized carbon translocated to the host by symbionts $\left(T_{\mathrm{S}}\right)$ for Stylophora pistillata at $\mathrm{pH}_{T} 8.1$ and 7.2. Data are means \pm standard error of means of $n=3$ measurements. Chase intervals with different letters (A to D) are significantly different.

when bicarbonate concentration was increased in seawater, independently of the $\mathrm{pH}$ conditions. In addition, Goiran et al. (1996) showed that the reduction in the rate of net photosynthesis per chlorophyll in the species Galaxea fascicu- laris was higher in a system in which bicarbonate was decreased rather than in a system with increased bicarbonate and low $\mathrm{pH}$. Altogether, these results suggest that DIC limitation of the photosynthesis is a general feature for several coral species and their associated symbionts, despite the presence of CCM. It has been shown that CCM efficiency differs between algal species (Tortell, 2000), and coral symbionts might have particularly low efficiencies.

Despite an enhancement of the cell-specific productivity, areal rates of gross photosynthesis were lowered at $\mathrm{pH}_{T} 7.2$ because of the lowering of the zooxanthellae concentration in the corals subject to long-term seawater acidification. This decrease in symbiont concentration was also observed for a lower decrease in $\mathrm{pH}_{T}$ (Krief et al., 2010; Kaniewska et al., 2012). As a consequence, the total autotrophic carbon acquired by the symbiotic association, estimated from the areal rates of gross photosynthesis, was $22 \%$ lower at $\mathrm{pH}_{T} 7.2$ than at $\mathrm{pH}_{T} 8.1\left(7.9 \mu \mathrm{g} \mathrm{C} \mathrm{cm}{ }^{-2} \mathrm{~h}^{-1}\right.$ instead of $\left.10.1 \mu \mathrm{g} \mathrm{C}^{-2} \mathrm{~h}^{-1}\right)$. This decrease in autotrophic carbon acquisition, also observed in previous long-term expositions to relatively low pHs (Reynaud et al., 2003; Anthony et al., 2008; Iguchi et al., 2012; Kaniewska et al., 2012), can have detrimental impacts for the carbon budget and the health of the corals. The model used in this study (summarized in Fig. 5), however, shows that the coral host acquired the same amount of autotrophic carbon under both pHs (5.5 and $6.1 \mu \mathrm{g} \mathrm{C} \mathrm{cm}^{-2} \mathrm{~h}^{-1}$ for $\mathrm{pH}_{T} 7.2$ and 8.1, respectively). This was achieved following an increase in the amount of carbon translocated per symbiont cell, and in the percent of translocation in corals maintained at $\mathrm{pH}_{T} 7.2$ compared to those at $\mathrm{pH}_{T}$ 8.1. Since respiration rates of the host and the symbionts 

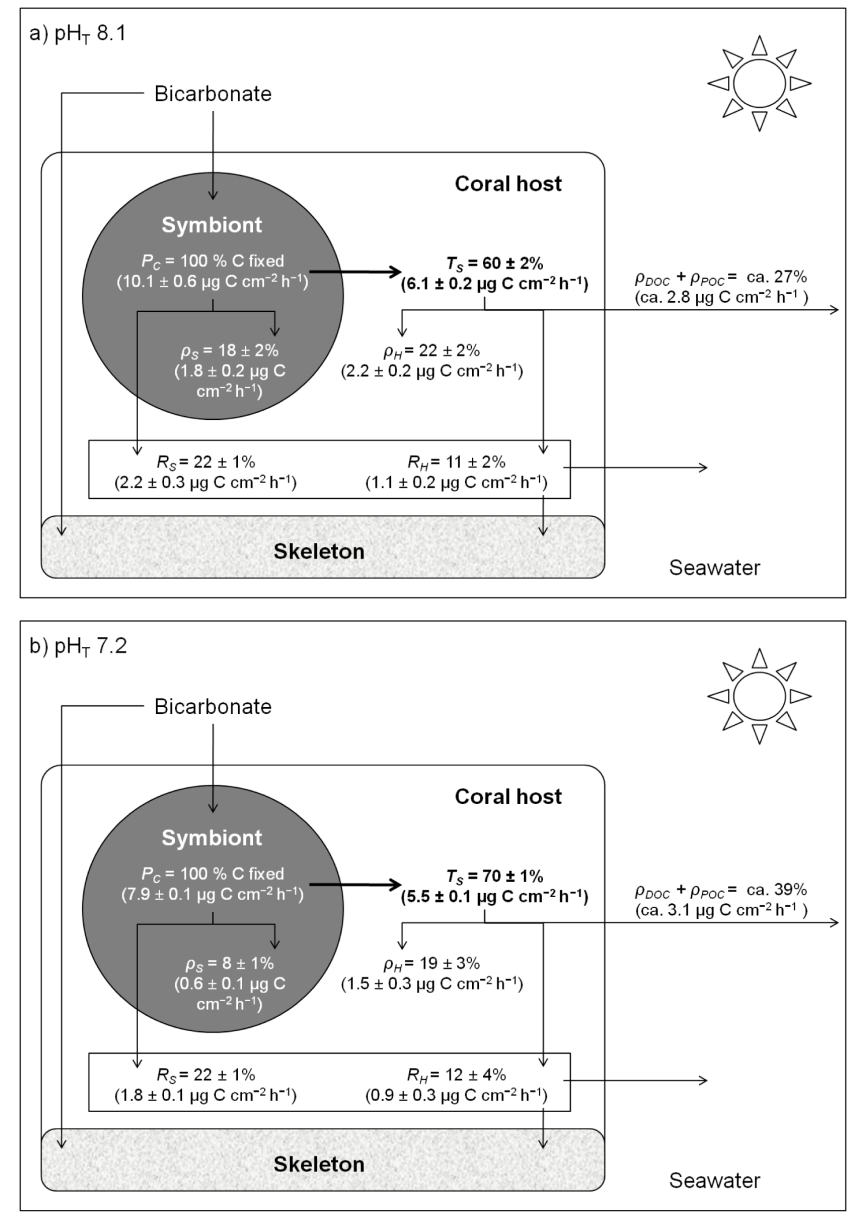

Fig. 5. Mass-balanced results of photosynthate translocation and carbon budget in Stylophora pistillata under (a) $\mathrm{pH}_{T}$ 8.1, and (b) $\mathrm{pH}_{T} 7.2$ based on ${ }^{13} \mathrm{C}$ experiments after $48 \mathrm{~h}$. Symbols are defined in the text and summarized in Table 2. Data are means \pm standard error of means of $n=3$ measurements.

remained unchanged under both conditions (ca. 1 and $2 \mu \mathrm{g} \mathrm{C}$ $\mathrm{cm}^{-2} \mathrm{~h}^{-1}$ or $12 \%$ and $22 \%$ of the total carbon was respired by the host and the symbionts, respectively, under both $\mathrm{pHs}$ ), as were the losses of carbon as DOC and POC (ca. $3 \mu \mathrm{g} \mathrm{C}$ $\mathrm{cm}^{-2} \mathrm{~h}^{-1}$ under both $\mathrm{pHs}$ ), the host conserved in both conditions ca. $20 \%$ of the autotrophically acquired carbon in its tissue after $48 \mathrm{~h}$, although with a slightly lower total amount for corals under $\mathrm{pH}_{T} 7.2$ than $\mathrm{pH}_{T} 8.1$ (1.5 compared to $2.2 \mu \mathrm{g} \mathrm{C} \mathrm{cm}{ }^{-2} \mathrm{~h}^{-1}$ ). This lower amount matches with the lower amount of proteins.

The higher percent of translocation in corals at $\mathrm{pH}_{T} 7.2$ can be the result of a lower carbon demand of the symbionts (in lower areal concentration in the host tissue), and/or to a higher demand from the host through, for example, an increased release of host factors (HRFs) (Muscatine, 1967; Grant et al., 1998; Davy and Cook, 2001). Overall, this observation is beneficial for the host over time, which can maintain a certain protein level (although lower at $\mathrm{pH}_{T} 7.2$ than at $\mathrm{pH}_{T}$ 8.1), but not for the symbionts, which are the losers under low $\mathrm{pH}$. Indeed, the amount of carbon remaining in the symbionts after $48 \mathrm{~h}$ dropped from $18 \%$ (or $1.8 \mu \mathrm{g}$ $\mathrm{C} \mathrm{cm}^{-2} \mathrm{~h}^{-1}$ ) of the photosynthesized carbon in corals at $\mathrm{pH}_{T} 8.1$ to $8 \%$ (or $0.6 \mu \mathrm{g} \mathrm{Cm}^{-2} \mathrm{~h}^{-1}$ ) in corals at $\mathrm{pH}_{T} 7.2$ (Fig. 5). In other words, there was a $33 \%$ decrease in the symbiont cell-specific carbon incorporation rate at $\mathrm{pH}_{T} 7.2$ compared to $\mathrm{pH}_{T} 8.1$ (from $1.5 \times 10^{-6} \mu \mathrm{g} \mathrm{C}$ cell $^{-1} \mathrm{~h}^{-1}$ at $\mathrm{pH}_{T} 8.1$ to $0.9 \times 10^{-6} \mu \mathrm{g} \mathrm{C}$ cell ${ }^{-1} \mathrm{~h}^{-1}$ at $\mathrm{pH}_{T}$ 7.2). Such low carbon incorporation in symbiont cells at $\mathrm{pH}_{T} 7.2$ is the best explanation for the bleaching observed. Symbionts have fewer building blocks to construct new biomass or to grow and replace the dying cells. This observation therefore mitigates the positive effect, on the host carbon budget, of higher percent carbon translocation. Under the very low $\mathrm{pH}_{T}$ conditions such as those applied in this study, the coral host can survive for some time with the same amount of autotrophically acquired carbon, but it is at the detriment of its population of symbionts. This population had severely declined after six months at $\mathrm{pH}_{T} 7.2$ compared to the population of control corals, and might continue decreasing up to the level at which there will be no photosynthate production and translocation anymore. For the host, the increased photosynthate translocation cannot even maintain its biomass in the long term since the total protein content has decreased in colonies maintained at $\mathrm{pH}_{T}$ 7.2. Questions remaining open are whether the symbiotic association can remain on the fragile equilibrium observed in this study in the long term or if the symbiont physiology will further decline; or how the symbiotic association will be impacted when maintained very long term under a smaller $\mathrm{pH} / p \mathrm{CO}_{2}$ perturbation; and, finally, what will be the cross effect of increased $p \mathrm{CO}_{2}$ and seawater temperature on the carbon translocation and budget in such symbioses.

Acknowledgements. We would like to thank O. Kolesnikova and $\mathrm{S}$. Cohen of The Interuniversity Institute for Marine Science in Eilat (IUI), as well as C. Rottier and S. Sikorski of the Centre Scientifique de Monaco (CSM) for laboratory assistance. We thank also D. Allemand, Director of the CSM, for scientific support as well as two anonymous reviewers and Jean-Pierre Gattuso for improving the manuscript. Funding for this project was provided by the CSM, the Institut Universitaire Européen de la Mer, the IUI and the Natural Sciences and Engineering Research Council of Canada (grant \# ES D3 - 378797 - 2009 to PT).

Edited by: H. Kitazato

\section{References}

Anthony, K. R. N. and Fabricius, K. E.: Shifting roles of heterotrophy and autotrophy in coral energy budgets at variable turbidity, J. Exp. Mar. Biol. Ecol., 252, 221-253, doi:10.1016/S00220981(00)00237-9, 2000. 
Anthony, K. R. N., Kline, D. I., Diaz-Pulido, G., Dove, S., and Hoegh-Guldberg, O.: Ocean acidification causes bleaching and productivity loss in coral reef builders, Proc. Natl. Acad. Sci. USA, 105, 17442-17446, doi:10.1073/pnas.0804478105, 2008.

Barry, J. P., Tyrrell, T., Hansson, L., and Gattuso, J.-P.: $\mathrm{CO}_{2}$ targets for ocean acidification perturbation experiments, in: Guide to best practices for ocean acidification research and data reporting, edited by: Riebesell, U., Fabry, V. J., Hansson, L., and Gattuso, J.-P., Publications Office of the European Union, Luxembourg, 53-66, 2010.

Brading, P., Warner, M. E., Davey, P., Smith, D. J., Achterberg, E. P., and Suggetta, D. J.: Differential effects of ocean acidification on growth and photosynthesis among phylotypes of Symbiodinium (Dinophyceae), Limnol. Oceanogr., 56, 927-938, doi:10.4319/lo.2011.56.3.0927, 2011.

Crawley, A., Kline, D. I., Dunn, S., Anthony, K. R. N., and Dove, S.: The effect of ocean acidification on symbiont photorespiration and productivity in Acropora formosa, Glob. Change Biol., 16, 851-863, doi:10.1111/j.1365-2486.2009.01943.x, 2010.

Davies, P. S.: The role of zooxanthellae in the nutritional energy requirements of Pocillopora eydouxi, Coral Reefs, 2, 181-186, 1984.

Davies, P. S.: Effects of daylight variations on the energy budgets of shallow-water corals, Mar. Biol., 108, 137-144, 1991.

Davy, S. K. and Cook, C. B.: The influence of "host release factor" on carbon release by zooxanthellae isolated from fed and starved Aiptasia pallida (Verrill), Comp. Biochem. Physiol. A Mol. Integr. Physiol., 129, 487-494, 2001.

Doney, S. C., Fabry, V. J., Feely, R. A., and Kleypas, J. A.: Ocean acidification: the other $\mathrm{CO}_{2}$ problem, Ann. Rev. Mar. Sci., 1, 169-192, doi:10.1146/annurev.marine.010908.163834, 2009.

Edmunds, P. J. and Davies, P. S.: An energy budget for Porites porites (Scleractinia), Mar. Biol., 92, 339-347, 1986.

Erez, J.: Vital effect on stable-isotope composition seen in foraminifera and coral skeletons, Nature, 273, 199-202, 1978.

Erez, J., Reynaud, S., Silverman, J., Scheinder, K., and Allemand, D.: Coral calcification under ocean acidification and global change, in: Coral reefs: an ecosystem in transition, edited by: Dubinsky, Z., and Stambler, N., Springer, Heidelberg, 151-176, 2011.

Fine, M. and Tchernov, D.: Scleractinian coral species survive and recover from decalcification, Science, 315, 1811, doi:10.1126/science.1137094, 2007.

Furla, P., Galgani, I., Durand, I., and Allemand, D.: Sources and mechanisms of inorganic carbon transport for coral calcification and photosynthesis, J. Exp. Biol., 203, 3445-3457, 2000.

Gattuso, J.-P. and Jaubert, J.: Effect of light on oxygen and carbon dioxide fluxes and on metabolic quotients measured in situ in a zooxanthellate coral, Limnol. Oceanogr., 35, 1796-1804, 1990.

Godinot, C., Houlbrèque, F., Grover, R., and Ferrier-Pagès, C.: Coral uptake of inorganic phosphorus and nitrogen negatively affected by simultaneous changes in temperature and $\mathrm{pH}, \mathrm{PLoS}$ ONE, 6, e25024, doi:10.1371/journal.pone.0025024, 2011.

Goiran, C., Al-Moghrabi, S., Allemand, D., and Jaubert, J.: Inorganic carbon uptake for photosynthesis by the symbiotic coral /dinoflagellate association I. Photosynthetic performances of symbionts and dependence on sea water bicarbonate, J. Exp. Mar. Biol. Ecol., 199, 207-225, 1996.
Grant, A. J., Rémond, M., and Hinde, R.: Low molecular-weight factor from Plesiastrea versipora (Scleractinia) that modifies release and glycerol metabolism of isolated symbiotic algae, Mar. Biol., 130, 553-557, 1998.

Grover, R., Maguer, J. F., Reynaud-Vaganay, S., and Ferrier-Pagès, C.: Uptake of ammonium by the scleractinian coral Stylophora pistillata: Effect of feeding, light, and ammonium concentrations, Limnol. Oceanogr., 47, 782-790, 2002.

Hoegh-Guldberg, O., Mumby, P. J., Hooten, A. J., Steneck, R. S., Greenfield, P., Gomez, E., Harvell, C. D., Sale, P. F., Edwards, A. J., Caldeira, K., Knowlton, N., Eakin, C. M., Iglesias-Prieto, R., Muthiga, N., Bradbury, R. H., Dubi, A., and Hatziolos, M. E.: Coral reefs under rapid climate change and ocean acidification, Science, 318, 1737-1742, doi:10.1126/science.1152509, 2007.

Houlbrèque, F., Rodolfo-Metalpa, R., Jeffrey, R., Oberhänsli, F., Teyssier, J.-L., Boisson, F., Al-Trabeen, K., and Ferrier-Pagès, C.: Effects of increased $p \mathrm{CO} 2$ on zinc uptake and calcification in the tropical coral Stylophora pistillata, Coral Reefs, 31, 101109, doi:10.1007/s00338-011-0819-2, 2012.

Iguchi, A., Ozaki, S., Nakamura, T., Inoue, M., Tanaka, Y., Suzuki, A., Kawahata, H., and Sakai, K.: Effects of acidified seawater on coral calcification and symbiotic algae on the massive coral Porites australiensis, Mar. Environ. Res., 73, 32-36, doi:10.1016/j.marenvres.2011.10.008, 2012.

Kaniewska, P., Campbell, P. R., Kline, D. I., RodriguezLanetty, M., Miller, D. J., Dove, S., and Hoegh-Guldberg, O.: Major cellular and physiological impacts of ocean acidification on a reef building coral, PLoS ONE, 7, e34659, doi:10.1371/journal.pone.0034659, 2012.

Krief, S., Hendy, E. J., Fine, M., Yam, R., Meibom, A., Foster, G. L., and Shemesh, A.: Physiological and isotopic responses of scleractinian corals to ocean acidification, Geochimica Cosmochim. Acta, 74, 4988-5001, doi:10.1016/j.gca.2010.05.023, 2010.

Kroeker, K. J., Kordas, R. L., Crim, R. N., and Singh, G. G.: Meta-analysis reveals negative yet variable effects of ocean acidification on marine organisms, Ecol. Lett., 13, 1419-1434, doi:10.1111/j.1461-0248.2010.01518.x, 2010.

Kurihara, H. and Shirayama, Y.: Effects of increased atmospheric $\mathrm{CO}_{2}$ on sea urchin early development, Mar. Ecol. Prog. Ser., 274, 161-169, 2004.

Leggat, W., Badger, M. R., and Yellowlees, D.: Evidence for an Inorganic carbon-concentrating mechanism in the symbiotic dinoflagellate Symbiodinium sp., Plant Physiol., 121, 1247-1255, 1999.

Lewis, E. and Wallace, D. W. R.: Program developed for $\mathrm{CO}_{2}$ System Calculations, ORNL/CDIAC-105, Oak Ridge Natl. Lab., US Dep. Energy, Oak Ridge, Tenn., 1998.

Loram, J. E., Trapido-Rosenthal, H. G., and Douglas, A. E.: Functional significance of genetically different symbiotic algae Symbiodinium in a coral reef symbiosis, Mol. Ecol., 16, 4849-4857, doi:10.1111/j.1365-294X.2007.03491.x, 2007.

Marubini, F. and Thake, B.: Bicarbonate addition promotes coral growth, Limnol. Oceanogr., 44, 716-720, 1999.

Marubini, F., Ferrier-Pagès, C., Furla, P., and Allemand, D.: Coral calcification responds to seawater acidification: a working hypothesis towards a physiological mechanism, Coral Reefs, 27, 491-499, doi:10.1007/s00338-008-0375-6, 2008.

Muscatine, L.: Glycerol excretion by symbiotic algae from corals and Tridacna and its control by the host, Science 156, 516-519, 
1967.

Muscatine, L., McCloskey, L. R., and Marian, R. E.: Estimating the daily contribution of carbon from zooxanthellae to coral animal respiration, Limnol. Oceanogr., 26, 601-611, 1981.

Muscatine, L., Falkowski, P. G., Porter, J. W., and Dubinsky, Z.: Fate of photosynthetic fixed carbon in light- and shade-adapted colonies of the symbiotic coral Stylophora pistillata, Proc. R. Soc. Lond. B, 222, 181-202, 1984.

Reynaud, S., Leclercq, N., Romaine-Lioud, S., Ferrier-Pagès, C., Jaubert, J., and Gattuso, J. P.: Interacting effects of $\mathrm{CO}_{2}$ partial pressure and temperature on photosynthesis and calcification in a scleractinian coral, Glob. Change Biol., 9, 1660-1668, doi:10.1046/j.1365-2486.2003.00678.x, 2003.

Rodolfo-Metalpa, R., Richard, C., Allemand, D., Bianchi, C. N., Morri, C., and Ferrier-Pagès, C.: Response of zooxanthellae in symbiosis with the Mediterranean corals Cladocora caespitosa and Oculina patagonica to elevated temperatures, Mar. Biol., 150, 45-55, doi:10.1007/s00227-006-0329-x, 2006.

Rodolfo-Metalpa, R., Martin, S., Ferrier-Pagès, C., and Gattuso, J.-P.: Response of the temperate coral Cladocora caespitosa to mid- and long-term exposure to $p \mathrm{CO} 2$ and temperature levels projected for the year 2100AD, Biogeosciences, 7, 289-300, doi:10.5194/bg-7-289-2010, 2010.

Santos, S. R., J. , T. D., Kinzie, R. A., Hidaka, M., Sakai, K., and Coffroth, M. A.: Molecular phylogeny of symbiotic dinoflagellates inferred from partial chloroplast large subunit (23S)-rDNA sequences, Mol. Phylogenet. Evol., 23, 97-111, 2002.

Scheinder, K. and Erez, J.: The effect of carbonate chemistry on calcification and photosynthesis in the hermatypic coral Acropora eurystoma, Limnol. Oceanogr., 51, 1284-1293, doi:10.4319/lo.2006.51.3.1284, 2006
Smith, P. K., Khrohn, R. I., Hermanson, G. T., Malia, A. K., Gartner, F. H., Provenzano, M. D., Fujimoto, E. K., Goeke, N. M., Olson, B. J., and Klenk, D. C.: Measurement of protein using bicinchoninic acid, Anal. Biochem., 150, 76-85, 1985.

Tortell, P. D.: Evolutionary and ecological perspectives on carbon acquisition in phytoplankton, Limnol. Oceanogr., 45, 744-750, 2000.

Tremblay, P., Ferrier-Pagès, C., Maguer, J. F., Rottier, C., Legendre, L., and Grover, R.: Controlling effects of irradiance and heterotrophy on carbon translocation in the temperate coral Cladocora caespitosa, PLoS ONE, 7, e44672, doi:10.1371/journal.pone.0044672, 2012a.

Tremblay, P., Grover, R., Maguer, J. F., Legendre, L., and FerrierPagès, C.: Autotrophic carbon budget in the coral tissue: a new ${ }^{13}$ C-based model of photosynthate translocation, J. Exp. Biol., 215, 1384-1393, doi:10.1242/jeb.065201, 2012b.

Tremblay, P., Naumann, M. S., Sikorski, S., Grover, R., and FerrierPagès, C.: Experimental assessment of organic carbon fluxes in the scleractinian coral Stylophora pistillata during a thermal and photo stress event, Mar. Ecol. Prog. Ser., 453, 63-77, doi:10.3354/meps09640, 2012c.

Veal, C. J., Carmi, M., Fine, M., and Hoegh-Guldberg, O.: Increasing the accuracy of surface area estimation using single wax dipping of coral fragments, Coral Reefs, 29, 893-897, doi:10.1007/s00338-010-0647-9, 2010.

Venn, A., Tambutté, É., Holcomb, M., Laurent, J., Allemand, D., and Tambutté, S.: Impact of seawater acidification on $\mathrm{pH}$ at the tissue-skeleton interface and calcification in reef corals, Proc. Natl. Acad. Sci. USA, 110, 1634-1639, doi:10.1073/pnas.1216153110, 2013. 